\title{
MATURATION CURVES AND DEGREE-DAYS ACCUMULATION FOR FRUITS OF 'FOLHA MURCHA' ORANGE TREES
}

\author{
Neusa Maria Colauto Stenzel ${ }^{1 *}$; Carmen Silvia Vieira Janeiro Neves²; Celso Jamil Marur³; \\ Maria Brígida dos Santos Scholz ; José Carlos Gomes ${ }^{4}$ \\ ${ }^{I}$ IAPAR - Área de Fitotecnia, C.P. 481 - 86001-970 - Londrina, PR - Brasil. \\ ${ }_{3}^{2} U E L$ - Depto. de Agronomia, C.P. 6001 - 86051-990 - Londrina, PR - Brasil. \\ ${ }^{3}$ IAPAR - Área de Ecofisiologia. \\ ${ }^{4}$ IAPAR - Área de Bioestatística. \\ *Corresponding author <nstenzel@iapar.br>
}

ABSTRACT: The effect of thermal summation on orange fruit growth on different rootstocks has not been studied for the State of Paraná, Brazil. This research evaluated the growth of fruits by means of maturation curves, and quantified the growing degree-days (GDD) accumulation required for fruit maturation in 'Folha Murcha' orange trees budded on 'Rangpur' lime, 'Volkamer' lemon, 'Sunki' mandarin, and 'Cleopatra' mandarin, in Paranavaí and Londrina, PR. In both locations and all rootstocks, the fruits showed evolution in total soluble solids (TSS) content in relation to GDD accumulation, with a quadratic tendency of curve fitting; total titratable acidity (TTA) had an inverse quadratic fitting, and the (TSS/ TTA) ratio showed a positive linear regression. Fruits in Paranavaí presented a higher development rate towards maturity than those in Londrina, for all rootstocks. The advancing of the initial maturation stage of fruits in Paranavaí in relation to those in Londrina occurred in the following descending order: 'Volkamer' lemon (92 days), 'Cleopatra' mandarin (81 days), 'Sunki' mandarin (79 days), 'Rangpur' lime (77 days). In Londrina, trees on 'Rangpur' lime and 'Volkamer' lemon were ready for harvest 8 and 15 days before those on the 'Cleopatra' and 'Sunki' mandarins, respectively. In Paranavaí, the beginning of fruit maturation in trees on 'Volkamer' lemon occurred 15, 19, and 28 days earlier than on 'Rangpur' lime, 'Cleopatra' mandarin, and 'Sunki' mandarin, respectively. Considering $12.8^{\circ} \mathrm{C}$ as the lower base temperature, the thermal sum for fruit growth and maturation of 'Folha Murcha' orange ranged from 4,462 to 5,090 GDD. Key words: Citrus sinensis, thermal summation, juice quality, rootstocks

\section{CURVAS DE MATURAÇÃO E GRAUS-DIA ACUMULADOS PARA FRUTOS DE PLANTAS DE LARANJEIRA 'FOLHA MURCHA'}

\begin{abstract}
RESUMO: O efeito da soma térmica no crescimento do fruto de laranja em diferentes porta-enxertos não tem sido estudado no Estado do Paraná, Brasil. Esta pesquisa avaliou o crescimento dos frutos por meio de curvas de maturação e quantificou os graus-dia acumulados (GDA) necessários para a maturação dos frutos em laranjeiras 'Folha Murcha' enxertadas em limão 'Cravo', limão 'Volcameriano', tangerina 'Sunki' e tangerina 'Cleópatra', em Paranavaí e Londrina, PR. Para os dois locais e em todos os porta-enxertos, os frutos apresentaram evolução do teor de sólidos solúveis totais (SST) em relação ao acúmulo de graus-dia com ajuste de tendência quadrática da curva de regressão; a acidez titulável total (ATT) com ajuste quadrático inverso e o ratio (SST/ATT) regressão linear positiva. Os frutos em Paranavaí apresentaram maior índice de maturação do que em Londrina para todos os porta-enxertos, com antecipação do ponto inicial de maturação na seguinte ordem: limão 'Volcameriano' (92 dias), tangerina 'Cleópatra' (81 dias), tangerina 'Sunki' (79 dias), limão ‘Cravo' (77 dias). Em Londrina, as plantas sobre os limões ‘Cravo’e 'Volcameriano’ apresentaram início da colheita 8 e 15 dias antes daquelas nas tangerinas 'Cleópatra' e 'Sunki', respectivamente. Em Paranavaí, o início da maturação dos frutos das plantas em limão 'Volcameriano' ocorreu 15, 19 e 28 dias mais precoce que o limão 'Cravo', tangerina 'Cleópatra' e tangerina 'Sunki', respectivamente. A soma térmica para o crescimento e maturação dos frutos de laranja 'Folha Murcha' variou de 4.462 a 5.090 GDA. Palavras-chave: Citrus sinensis, soma térmica, qualidade de suco, porta-enxertos
\end{abstract}

\section{INTRODUCTION}

Orange production in the State of Paraná is concentrated in the Northern and Northwestern re- gions; 'Folha Murcha' (Citrus sinensis L. Osbeck) is the second most planted orange variety, because of its characteristics for both, the industry and the fresh fruit market. 
The most important rootstock used for this variety is the 'Rangpur' lime. However, because diseases can cause great damages when a single rootstock is used, alternative rootstocks must be sought for each region to ensure productivity and quality (Pompeu Jr., 1991).

The maturation curve for citrus fruits is influenced by air temperature, solar radiation, water availability in the soil, topography, elevation, exposure surface in the plant, and varietal characteristics (Ortolani et al., 1991). One of the most frequently used methods to relate temperature and plant development is the thermal summation, or accumulative growing degreedays (GDD), defined as the sum of mean daily temperatures above a lower base temperature and below a maximum threshold temperature, for the plant to complete its total cycle or to reach a phenological stage (Souza, 1990). This calculation is used to predict phenological sub-periods, staggered production, genetic breeding programming, harvest season planning, and climatic zoning (Montenegro, 1980; Ometto, 1981; Warrington \& Kanemasu, 1983; Roberto et al., 2005). In the State of São Paulo, orange varieties require between 2,500 and 3,600 GDD for fruits to attain maturation (Ortolani et al., 1991). The lower base temperature is taken as $12.8^{\circ} \mathrm{C}$ and the threshold temperature $36^{\circ} \mathrm{C}$.

The effect of the thermal summation on fruit development under different citrus scion/rootstock combinations is poorly studied, and no information on the maturation of fruits from 'Folha Murcha' orange trees is available for the State of Paraná. Therefore, the objective of this work was to study the maturation curves and to quantify the degree-days sums required for development of fruits from 'Folha Murcha' orange trees on four rootstocks in the Northern and Northwestern regions of Paraná.

\section{MATERIAL AND METHODS}

Fruits from 'Folha Murcha' orange trees were evaluated, budded onto 'Rangpur' lime (Citrus limonia Osb.), 'Volkamer' lemon (Citrus volkameriana Ten. and Pasq.), 'Sunki' mandarin (Citrus sunki Hort. ex Tan.), and 'Cleopatra' mandarin (Citrus reshni Hort.

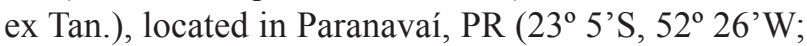
elevation $480 \mathrm{~m}$ ), in the Northwestern region and in Londrina, PR ( $23^{\circ} 22^{\prime} \mathrm{S}, 51^{\circ} 10^{\prime} \mathrm{W}$; elevation $\left.585 \mathrm{~m}\right)$, in the Northern part of the state. In Paranavaí, the soil is a latosolic dystrophic Red Argisol, with $80 \mathrm{~g} \mathrm{~kg}^{-1}$ clay, $10 \mathrm{~g} \mathrm{~kg}^{-1}$ silt, and $910 \mathrm{~g} \mathrm{~kg}^{-1}$ sand in the $0-25$ $\mathrm{cm}$ layer. In Londrina, the soil has been characterized as a Typic Hapludox, containing $630 \mathrm{~g} \mathrm{~kg}^{-1}$ clay, 180 $\mathrm{g} \mathrm{kg}^{-1}$ silt, and $190 \mathrm{~g} \mathrm{~kg}^{-1}$ sand in the $0-25 \mathrm{~cm}$ layer.
The climate at both locations was classified as Cfa, according to Köppen. In Paranavaí the mean annual precipitation is $1,499 \mathrm{~mm}$, occurring mainly in spring and summer; the mean annual temperature is $22.1^{\circ} \mathrm{C}$, with a mean relative humidity of $69 \%$. In Londrina, the mean annual precipitation is $1,610 \mathrm{~mm}$, with a tendency to concentrate mainly during spring and summer; the mean annual temperature is $21.2^{\circ} \mathrm{C}$, with a mean relative humidity of $70.7 \%$.

From June 2002 to February 2003, ten fruits were monthly sampled from the four quadrants of the plants per plot, and evaluated for quality. Chemical analyses were carried on fruit juice extracted with an electric squeezer; total soluble solids content (TSS), determined in a manual refractometer, with results expressed in Brix degrees corrected to $20^{\circ} \mathrm{C}$. Total titratable acidity (TTA) was evaluated by titration with $\mathrm{NaOH}$ at $0.1 \mathrm{~N}$ (AOAC, 1990), and results were expressed as citric acid percentages. The maturation index or ratio was calculated by the relation between TSS and TTA.

The number of days until initial maturation of fruits in each treatment was determined from anthesis (full flowering period - August, 09, 2001 in Paranavaí and August, 02, 2001 in Londrina) until the TSS/TTA ratio reached 12 (beginning of harvest).

For both locations, accumulated growing degree-days (GDD) were calculated using minimum air temperature (Tm) and maximum air temperature (TM), with a lower base temperature $(\mathrm{Tb})$ of $12.8^{\circ} \mathrm{C}$ and an upper threshold temperature (TB) of $36^{\circ} \mathrm{C}$; and the following formulas, as suggested by Ometto (1981):

Formula A:

when: $\mathrm{Tm}>12.8^{\circ} \mathrm{C}$ and $\mathrm{TM}<36^{\circ} \mathrm{C}$

$\mathrm{GDD}=\frac{(\mathrm{TM}+\mathrm{Tm})}{2}-\mathrm{Tb}$

Formula B:

when: $\mathrm{Tm}<12.8^{\circ} \mathrm{C}$ and $\mathrm{TM}<36^{\circ} \mathrm{C}$

$\mathrm{GDD}=\frac{(\mathrm{TM}-\mathrm{Tb})^{2}}{2(\mathrm{TM}-\mathrm{Tm})}$

Formula C:

when: $\mathrm{Tm}>12.8^{\circ} \mathrm{C}$ and $\mathrm{TM}>36^{\circ} \mathrm{C}$

$\mathrm{GDD}=2 \frac{(\mathrm{TM}-\mathrm{Tm})(\mathrm{Tm}-\mathrm{Tb})+(\mathrm{TM}-\mathrm{Tm})^{2}-(\mathrm{TM}-\mathrm{TB})^{2}}{2(\mathrm{TM}-\mathrm{Tm})}$

The water balances for the period from June 2001 to February 2003 were calculated for both locations, according to the method of Thornthwaite \& Matter (1955), considering an available water storage capacity (AWSC) of $100 \mathrm{~mm}$, using the spreadsheet de- 
veloped by Rolim \& Sentelhas (1998). Graphs for the air and soil temperatures in the municipalities of Londrina and Paranavaí, during the months of June 2001 to February 2003 were also prepared with the data obtained from IAPAR's weather stations. Soil temperature was measured with a geothermometer, at 0900,1500 , and 2100 hours, at a $20 \mathrm{~cm}$ depth and the weighted mean was estimated through the formula: Tm $=\left(\mathrm{T}_{9 \mathrm{~h}}+\mathrm{T}_{15 \mathrm{~h}}+\left(2 \mathrm{xT}_{21 \mathrm{~h}}\right)\right) / 4$, where Tm is the mean temperature and $\mathrm{T}$ is the temperature at the respective times.

Data of total soluble solids, total titratable acidity, and the TSS/TTA ratio were analyzed as a function of growing accumulated degree-days fitting them to several regression models. Fitting was valued by the $\mathrm{F}$ test in the analysis of variance and the coefficient of determination was fitted to the number of parameters. The same procedure were applied to the mean TSS/TTA ratio of fruits of the four rootstocks, from Londrina and Paranavai, and the corresponding fitted polynomial lines in the period June 2 to February 3 were also obtained. Results were analyzed using the Statistical Analysis System software package (SAS Institute Inc., 2001).
In Paranavaí, fruits were collected from fourteen-year-old plants, in a randomized block design, with four rootstocks, three plants per plot, and four replicates. In Londrina, plants were eight years old, organized as a randomized block design, with four rootstocks, two plants per plot, and five replicates. At both locations, the plants were arranged in a row spacing of $7.0 \mathrm{~m} \times 4.0 \mathrm{~m}$.

\section{RESULTS AND DISCUSSION}

The estimated coefficients of determination of the polynomial equations of total soluble solids, total titratable acidity and the TSS/TTA ratio presented all a good fit, with statistical significance for all tested stocks at both locations (Figure 1 and Table 1). An increase in TSS content occurred during the fruit growth and a decline was observed from the beginning of maturation, indicating a quadratic tendency for all stocks, at both locations. Temperature oscillations and rainfall can be responsible for 60 to $70 \%$ of the variability in total soluble solids content (Albrigo, 1992). Higher soluble solids contents have been related to drought stress, due to the loss of water contained in

Table 1 - Coefficients of polynomial equations fitted to express total titratable acidity (TTA), total soluble solids (TSS) and the TSS/TTA ratio with growing accumulated degree-days from anthesis to maturation, and corresponding coefficients of determination for fruits from 'Folha Murcha' orange plants budded on four rootstocks, in the municipalities of Londrina, PR, and Paranavaí, PR, during the 2002 haverst.

\begin{tabular}{|c|c|c|c|}
\hline \multicolumn{4}{|c|}{ Londrina } \\
\hline Rootstocks & TTA & TSS & TSS/TTA ratio \\
\hline 'Rangpur' lime & $\begin{array}{l}\mathrm{y}=5.4509-0.0015 \mathrm{x}+1 \mathrm{E}-07 \mathrm{x}^{2} \\
\mathrm{r}^{2}=0.99 * *\end{array}$ & $\begin{array}{l}\mathrm{y}=-18.92+0.013 \mathrm{x}-1 \mathrm{E}-06 \mathrm{x}^{2} \\
\mathrm{r}^{2}=0.92 * *\end{array}$ & $\begin{array}{l}\mathrm{y}=-9.5492+0.0044 \mathrm{x} \\
\mathrm{r}^{2}=0.99 * *\end{array}$ \\
\hline $\begin{array}{l}\text { 'Cleopatra' } \\
\text { mandarin }\end{array}$ & $\begin{array}{l}\mathrm{y}=6.9127-0.0021 \mathrm{x}+2 \mathrm{E}-07 \mathrm{x}^{2} \mathrm{r}^{2} \\
=0.98^{* *}\end{array}$ & $\begin{array}{l}y=-18.12+0.0127 x-1 E-06 x^{2} \\
r^{2}=0.83 *\end{array}$ & $\begin{array}{l}\mathrm{y}=-8.9992+0.0042 \mathrm{x} \\
\mathrm{r}^{2}=0.98 * *\end{array}$ \\
\hline 'Sunki' mandarin & $\begin{array}{l}y=8.8838-0.0027 x+2 E-07 x^{2} r^{2} \\
=0.97 * *\end{array}$ & $\begin{array}{l}y=-25.562+0.015 x-1 E-06 x^{2} \\
r^{2}=0.96 * *\end{array}$ & $\begin{array}{l}y=-7.8494+0.0039 x \\
r^{2}=0.97 * *\end{array}$ \\
\hline 'Volkamer' lemon & $\begin{array}{l}\mathrm{y}=7.0036-0.0021 \mathrm{x}+2 \mathrm{E}-07 \mathrm{x}^{2} \mathrm{r}^{2} \\
=0.98 * *\end{array}$ & $\begin{array}{l}\mathrm{y}=-17.723+0.0121 \mathrm{x}-1 \mathrm{E}-06 \mathrm{x}^{2} \\
\mathrm{r}^{2}=0.91 * *\end{array}$ & $\begin{array}{l}\mathrm{y}=-9.0585+0.0043 \mathrm{x} \\
\mathrm{r}^{2}=0.98 * *\end{array}$ \\
\hline \multicolumn{4}{|c|}{ Paranavaí } \\
\hline Rootstocks & TTA & TSS & TSS/TTA ratio \\
\hline 'Rangpur' lime & $\begin{array}{l}\mathrm{y}=8.8398-0.0027 \mathrm{x}+2 \mathrm{E}-07 \mathrm{x}^{2} \mathrm{r}^{2} \\
=0.99 * *\end{array}$ & $\begin{array}{l}y=-19.994+0.0126 x-1 E-06 x^{2} \\
r^{2}=0.93 * *\end{array}$ & $\begin{array}{l}\mathrm{y}=-22.116+0.0074 \mathrm{x} \\
\mathrm{r}^{2}=0.99 * *\end{array}$ \\
\hline $\begin{array}{l}\text { 'Cleopatra' } \\
\text { mandarin }\end{array}$ & $\begin{array}{l}\mathrm{y}=9.0642-0.0028 \mathrm{x}+2 \mathrm{E}-07 \mathrm{x}^{2} \\
\mathrm{r}^{2}=0.98 * *\end{array}$ & $\begin{array}{l}\mathrm{y}=-19.1+0.0123 \mathrm{x}-1 \mathrm{E}-06 \mathrm{x}^{2} \\
\mathrm{r}^{2}=0.95 * *\end{array}$ & $\begin{array}{l}\mathrm{y}=-16.94+0.0062 \mathrm{x} \\
\mathrm{r}^{2}=0.96^{* *}\end{array}$ \\
\hline 'Sunki' mandarin & $\begin{array}{l}\mathrm{y}=8.8838-0.0027 \mathrm{x}+2 \mathrm{E}-07 \mathrm{x}^{2} \\
\mathrm{r}^{2}=0.97 * *\end{array}$ & $\begin{array}{l}y=-25.562+0.015 x-1 E-06 x^{2} \\
r^{2}=0.96 * *\end{array}$ & $\begin{array}{l}\mathrm{y}=-18.233+0.0063 \mathrm{x} \\
\mathrm{r}^{2}=0.98 * *\end{array}$ \\
\hline 'Volkamer' lemon & $\begin{array}{l}\mathrm{y}=7.0036-0.0021 \mathrm{x}+2 \mathrm{E}-07 \mathrm{x}^{2} \\
\mathrm{r}^{2}=0.98 * *\end{array}$ & $\begin{array}{l}\mathrm{y}=-14.158+0.0101 \mathrm{x}-1 \mathrm{E}-06 \mathrm{x} 2 \\
\mathrm{r}^{2}=0.84 *\end{array}$ & $\begin{array}{l}\mathrm{y}=-22.36+0.0077 \mathrm{x} \\
\mathrm{r}^{2}=0.97 * *\end{array}$ \\
\hline
\end{tabular}

Acidity and Brix: $y=a+b x+c x^{2}$. Ratio: $y=a+b x . x=$ growing degree-days. $*$ and $* *=$ significant at $5 \%$ and $1 \%$ probability, respectively. 

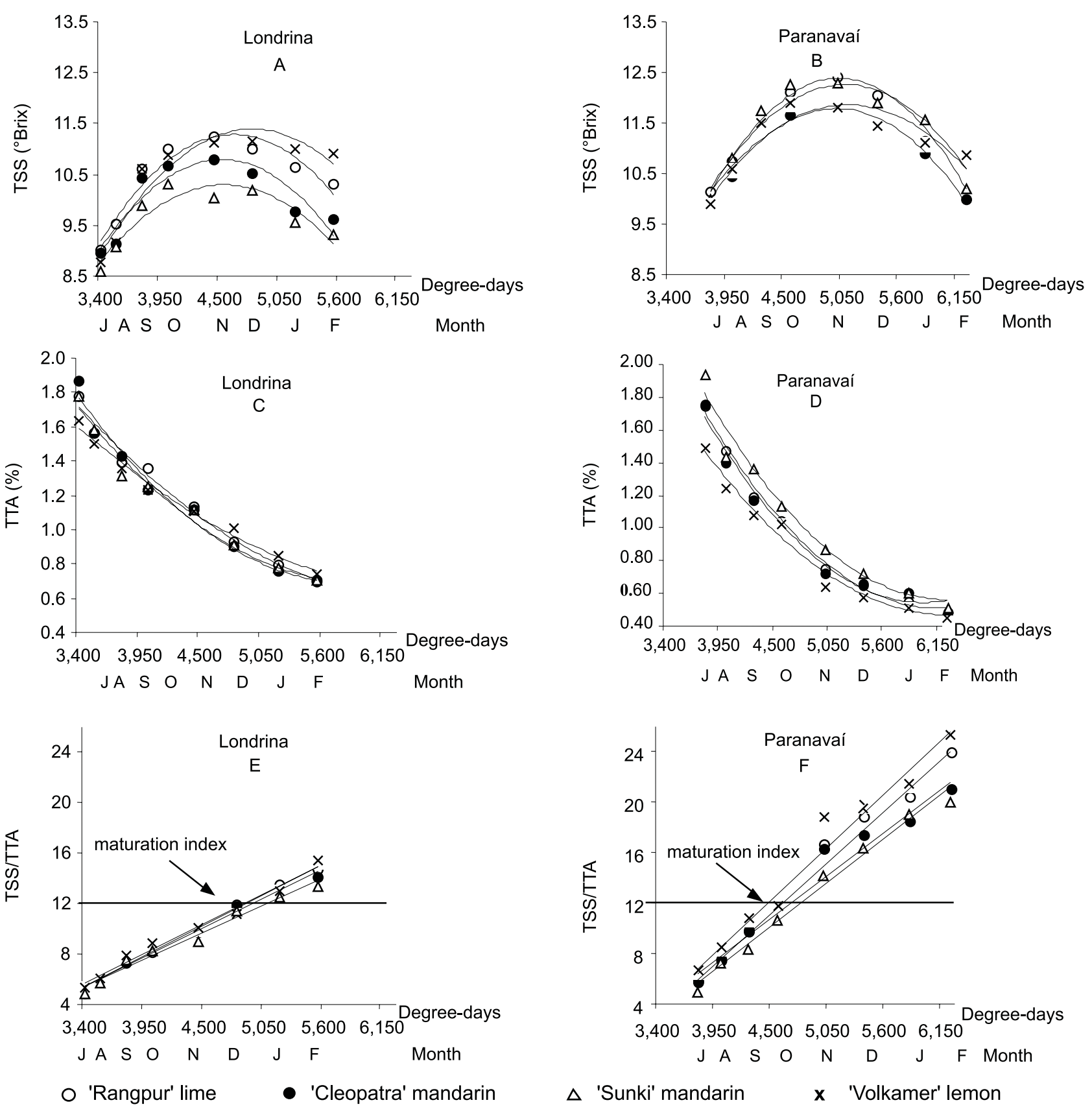

Figure 1 - Total soluble solids (TSS) in ${ }^{\circ}$ Brix (A and B), total titratable acidity (TTA) \% (C and D), and TSS/TTA ratio (E and F) data as a function of growing degree-days (GDD) accumulated since anthesis, in fruits from 'Folha Murcha' orange plants budded on four rootstocks, and corresponding fitted polynomial lines for the period June/02 to February /03, in the municipalities of Londrina, PR and Paranavaí, PR.

the fruits (Reuther \& Rios-Castaño, 1969). Excess precipitation can decrease soluble solids contents, possibly because the juice becomes diluted, especially during the maturation period (Chitarra \& Chitarra, 1979; Albrigo, 1992; Coelho et al., 1984).

Following accumulated degree-days during the fruit growth and maturation process, a decrease in acidity was observed in the fruits of plants on all stocks, at both locations (Figure $1-\mathrm{C}$ and D), with an inverse quadratic fitting. Russo (1984) and Jones et al. (1962) similarly observed decreasing in acidity during growth of fruits from 'Washington Navel' and 'Navelina' orange trees. Kimball (1984) reported that the decrease in acidity at maturation was directly related to fruit growth and to increased water absorption and retention capacity, with an interaction with respiratory activity. Higher temperatures can also induce a decrease in acid content (Nogueira, 1979).

The relationship between the TSS/TTA ratio and cumulative degree-days was best fitted with posi- 
tive linear regressions for fruits at both locations and all stocks (Figure 1 - E and F, and Table 1). The TSS/ TTA ratio values in relation to degree-days accumulation in Paranavaí presented a higher maturation index; therefore, maturation in Paranavaí occurs earlier than in Londrina, with a positive linear regression fitting for both locations (Figure 2). Chitarra \& Chitarra (1979) observed the same linear behavior for the TSS/TTA ratio for the 'Valência' orange, with a linear regression $\left(r^{2}=0.96\right)$. Marchi (1993) found similar results while studying 'Pera' orange maturation curves in the region of Bebedouro, SP. Also, Volpe et al. (2002) verified a high linear correlation between ratio and degree-days in fruits of 'Valencia' and 'Natal' oranges. The acid-

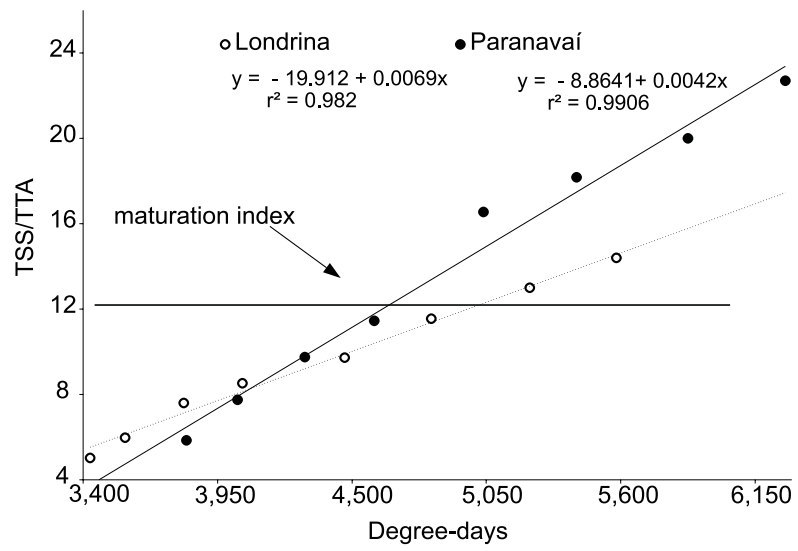

Figure 2 - TSS/TTA ratio data as a function of growing accumulated degree-days since anthesis, in fruits from 'Folha Murcha' orange plants budded on four rootstocks (mean), and corresponding fitted polynomial lines for the period June/02 to February 03, in the municipalities of Londrina, PR and Paranavaí, PR. ity contents were also best fitted to inverse polynomial regressions, while quadratic regressions showed the best fitting for soluble solids content.

The number of days for fruit growth and maturation ranged from 498 to 513 days in Londrina, and from 406 to 434 days in Paranavaí (Table 2). It can also be observed that the initial harvesting stage of fruits in Paranavaí in relation to those in Londrina was anticipated for the tested rootstocks: 'Rangpur' lime (77 days), 'Cleopatra' mandarin (81 days), 'Sunki' mandarin (79 days), and 'Volkamer' lemon (92 days). It was also verified that in Londrina, plants on 'Rangpur' lime and 'Volkamer' lemon were ready for harvest 8 and 15 days before those on the 'Cleopatra' and 'Sunki' mandarins, respectively. In Paranavaí, fruit harvest from plants on 'Volkamer' lemon occurred 15, 19 , and 28 days earlier than on 'Rangpur' lime, 'Cleopatra' mandarin, and 'Sunki' mandarin, respectively. This behavior indicates that, at each location, in addition to edaphic-climatic factors, the genetic characteristics of the rootstocks also contributed to influence the date harvest started.

Volpe (1992) reported that in the state of São Paulo, there are maturation season differences for citrus fruits among many regions due to altitude and latitude, which are conditioning factors of the temperature regime, with an expected difference of thirty days in the north of the state relative to its central region. Similarly, Coelho et al. (1984), studying 'Pera' orange fruits in Brazil, and Cooper et al. (1963), studying 'Valência' orange in USA, verified that citrus fruits reach the maturation index more quickly in regions with higher temperatures. According to Kimball (1984), under normal conditions temperature seems to

Table 2 - Cumulative growing degree-days, dates when anthesis and fruit maturation began, number of days from anthesis to beginning of fruit maturation for 'Folha Murcha' orange trees budded on four rootstocks in the municipalities of Londrina, PR, and Paranavaí, PR, during the 2002 harvest.

\begin{tabular}{lcccc}
\hline \multicolumn{5}{c}{ Londrina } \\
\hline Rootstocks & Date of anthesis & $\begin{array}{c}\text { Date when fruits } \\
\text { began maturation }\end{array}$ & $\begin{array}{c}\text { Number of days from anthesis } \\
\text { to beginning of fruit maturation }\end{array}$ & $\begin{array}{c}\text { Cumulative } \\
\text { degree-days }{ }^{\text {(GDD) }}\end{array}$ \\
\hline 'Sunki' mandarin & $08 / 02 / 01$ & $12 / 28 / 02$ & 513 & 5,090 \\
'Cleopatra' mandarin & $08 / 02 / 01$ & $12 / 21 / 02$ & 506 & 4,999 \\
'Rangpur' lime & $08 / 02 / 01$ & $12 / 13 / 02$ & 498 & 4,898 \\
'Volkamer' lemon & $08 / 02 / 01$ & $12 / 13 / 02$ & 498 & 4,897 \\
\hline & & \multicolumn{2}{c}{ Paranavaí } & 4,799 \\
\hline 'Sunki' mandarin & $08 / 09 / 01$ & $10 / 17 / 02$ & 434 & 4,668 \\
'Cleopatra' mandarin & $08 / 09 / 01$ & $10 / 08 / 02$ & 425 & 4,610 \\
'Rangpur' lime & $08 / 09 / 01$ & $10 / 04 / 02$ & 406 & 4,462 \\
'Volkamer' lemon & $08 / 09 / 01$ & $09 / 19 / 02$ & & 421 \\
\hline
\end{tabular}

${ }^{a}$ Beginning of maturation (Maturation index $=12$ ). ${ }^{\mathrm{b}}$ Growing degree-days accumulated in the period from anthesis until beginning of maturation. 
be the most important factor, although several factors such as rootstocks, varieties, soil conditions, stress caused by frost, diseases, drought, and high fruit yield, interfere on citrus fruit growth. In addition, Volpe et al. (2000) pointed out that the fruit maturation index is also greatly influenced by water balance, since water deficit during this period may influence the increase in TSS content and cause earlier maturation.

The thermal summation required for fruit growth and maturation in 'Folha Murcha' plants on the evaluated rootstocks (Table 2) showed the following descending order for Londrina and Paranavaí, respectively: 'Sunki' mandarin (5,090 GDD and 4,799 GDD), 'Cleopatra' mandarin (4,999 GDD and 4,668 GDD), 'Rangpur' lime (4,898 GDD and 4,610 GDD), and 'Volkamer' lemon (4,897 GDD and 4,462 GDD). Based on Table 2, the difference in thermal sums for fruits were $8.8 \%$ and $5.7 \%$ between the lowest and the highest value, for Paranavaí and Londrina, respectively. The thermal summation results in this work for both locations were near the value found by MartínezPérez (1999) for the conditions in the region of Bebedouro, SP, for fruits of 'Folha Murcha' orange onto 'Swingle' citrumelo, with a thermal sum of 4,789 GDD. Even though conceptually the thermal summation value should be constant regardless of location, this theory assumes that daily and nightly temperatures affect plant growth and development equally, and that other elements would have little significance when compared with the temperature effect. However, other variables (solar radiation, soil temperature, wa-

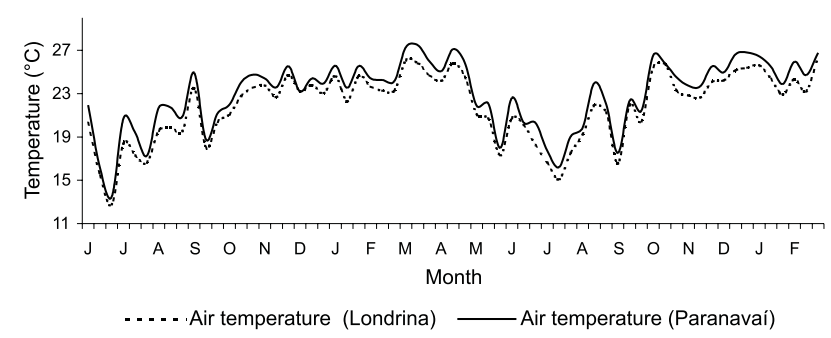

Figure 3 - Mean air temperature in the municipalities of Paranavaí and Londrina,PR, during the period June 2001 to February 2003.

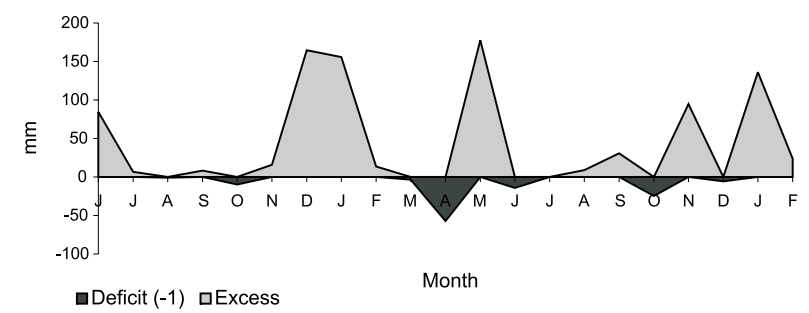

Figure 5 - Water balance in the municipality of Paranavaí,PR, for the period June 2001 to February 2003. ter availability, air humidity, wind, nutritional condition, and plant health) also affect plant metabolism and influence development of processes in citrus plants (Camargo et al., 1974). For Ortolani et al. (1991), the cumulative degree-days method presented limitations, but explained $80 \%$ of maturation evolution and could be used to compare regions. Reuther (1973) considered that in order to evaluate thermal summation in different locations, there should be a minimum of edaphoclimatic homogeneity between the areas comprised in the study.

The thermal summation differences obtained for fruits produced in Paranavaí and Londrina probably arose from the interaction among some factors. The mean air temperature in Paranavaí $\left(23.1^{\circ} \mathrm{C}\right)$ was higher than in Londrina $\left(22.0^{\circ} \mathrm{C}\right)$ (Figure 3$)$. The mean soil temperature was also higher in Paranavaí (25.3) than in Londrina (23.7) (Figure 4). The water deficit was more pronounced in Paranavaí (Figure 5) than in Londrina (Figure 6), due to lower water retention capacity of the soil in Paranavaí.

\section{CONCLUSIONS}

In both locations and all rootstocks, the fruits in 'Folha Murcha' orange plants showed evolution in total soluble solids content in relation to degree-days accumulation, with a quadratic tendency of regression fitting; total titratable acidity had an inverse quadratic fitting, and the TSS/TTA ratio a positive linear regression.

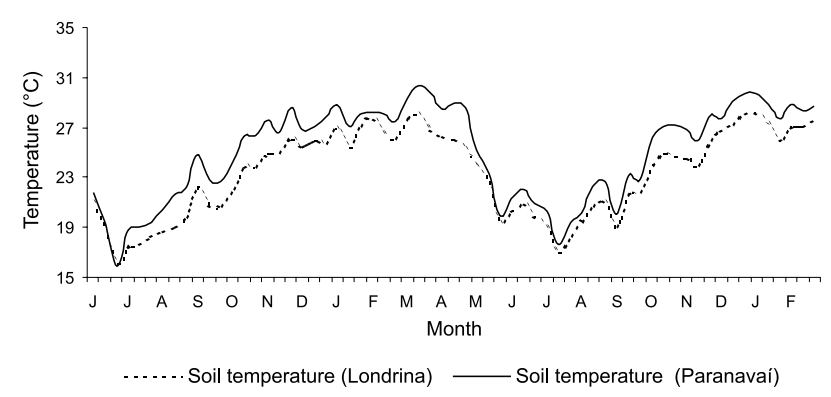

Figure 4 - Mean soil temperature in the municipalities of Paranavaí and Londrina, PR, for the period June 2001 to February 2003.

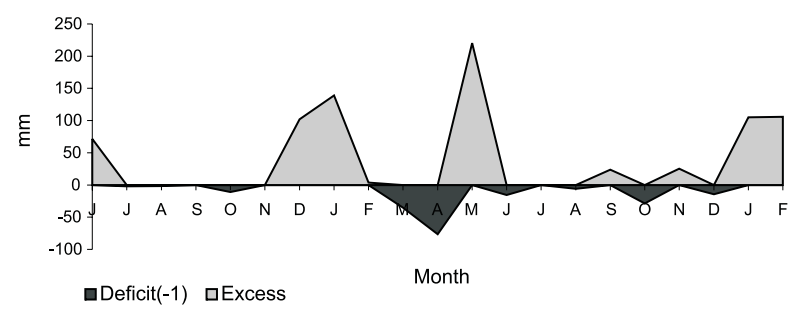

Figure 6 - Water balance in the municipality of Londrina, PR, for the period June 2001 to February 2003. 
Fruits of 'Folha Murcha' plants grafted onto the four rootstocks in Paranavaí had a higher maturation index than those in Londrina. In Paranavaí, 'Volkamer' lemon induced earlier fruit maturation than the other rootstocks. In Londrina, 'Volkamer' lemon and 'Rangpur' lime matured earlier than 'Cleopatra' and 'Sunki' mandarins.

The thermal summation for fruit growth and maturation of 'Folha Murcha' oranges ranged from 4,462 to 5,090 GDD.

\section{ACKNOWLEDGMENTS}

To CNPq and EMBRAPA, for the scholarships of Carmen S. J. V. Neves and Neusa M. C. Stenzel, respectively. To IAPAR for financial support.

\section{REFERENCES}

ALBRIGO, L.G. Influências ambientais no desenvolvimento de frutos cítricos. In: SEMINÁRIO INTERNACIONAL DE CITROS FISIOLOGIA, 2., Bebedouro, 1992. Anais. Campinas: Fundação Cargill, 1992. p.100-106.

ASSOCIATION OF OFFICIAL ANALYTICAL CHEMISTS - AOAC. Official methods of analysis. 15.ed. Arlington: AOAC, 1990.1298p.

CAMARGO, M.B.P.; PINTO, H.S.; PEDRO JR., M.J.; BRUNINI, O.; ALFONSI, R.R.; ORTOLANI, A.A. Aptidão climática de culturas agrícolas . In: SÃO PAULO (Estado). Secretaria de Agricultura de São Paulo. Zoneamento agrícola do Estado de São Paulo. São Paulo: CATI, 1974. v.1, p.89-105.

CHITARRA, A.B.; CHITARRA, M.I.F. Componentes físicos e químicos da laranja Valência (Citrus sinensis, L. Osbeck) em diversos estádios de maturação. In: CONGRESSO BRASILEIRO DE FRUTICULTURA, 5., Pelotas, 1979. Anais. Pelotas: SBF, 1979. v.2, p.563-586.

COELHO, Y.S.; POMPEU JR., J.; BASTOS, B.; DORNELLES, C.M.M.; SOUZA, E.S.; CALDAS, R.C. Maturation and quality of Pera sweet orange in Brazil. Proceedings of International Society of Citriculture, v.2, p.517-520, 1984.

COOPER, W.C.; PEYNADO, A.; FURR, J.R.; HILGEMAN, R.H.; CAHOON, G.A.; BOSWELL, S.B. Tree growth and fruit quality of Valencia oranges in relation to climate. Journal of the American Society for Horticultural Science, v.82, p.180-192, 1963.

JONES, W.W.; EMBLETON, T.W.; CREE, C.B. Temperature effects on acid Brix ratio in "Washington" oranges. Citrograph, v.47, p.132134, 1962

KIMBALL, D.A. Factors affecting the rate of maturation of citrus fruits. Proceedings of the Florida State Horticultural Society, v.97, p.4044, 1984.

MARCHI, R.J. Determinação das curvas de maturação da laranja Pêra de Bebedouro. Jaboticabal: UNESP/FCAV, 1993. 129p. (Dissertação - Mestrado).

MARTÍNEZ-PÉREZ, D. Desenvolvimento, produção e qualidade de laranjeiras doces (Citrus sinensis (L.) Osbeck). Jaboticabal: UNESP, 1999. 178p. (Tese - Doutorado).
MONTENEGRO, H.W.S. Clima e solo. In: RODRIGUEZ, O.; VIÉGAS, F.C.P. Citricultura brasileira. Campinas: Fundação Cargill, 1980. p.225-239.

NOGUEIRA, D.J.P. Citrus/Tecnologia de produção. O clima na citricultura. Informe Agropecuário, v.5, p.3-12, 1979.

OMETTO, J.C. Bioclimatologia vegetal. São Paulo: Ceres, 1981. 400p. ORTOLANI, A.A.; PEDRO JR., M.J.; ALFONSI, R.R. Agroclimatologia e o cultivo dos citros. In: RODRIGUEZ, O.; VIEGAS, F.C.P.; POMPEU JR., J.; AMARO; A.A. Citricultura brasileira. 2.ed. Campinas: Fundação Cargill, 1991. v.1, p.153-193.

POMPEU JR., J. Porta-enxertos. In: RODRIGUEZ, O.; VIEGAS, F.C.P.; POMPEU JR., J.; AMARO, A.A. Citricultura brasileira. 2.ed. Campinas: Fundação Cargill, 1991. v.1, p.265-280.

REUTHER, W. The citrus industry. Riverside: University of California, 1973. v.3, p.280-337: Climate and behavior.

REUTHER, W.; RIOS-CASTAÑO, D. Comparison of growth, maturation and composition of citrus fruits in subtropical California and tropical Colombia. In: INTERNATIONAL CITRUS SYMPOSIUM, 1., Riverside, 1969. Proceedings. Riverside, 1969. p.277-300.

ROBERTO, S.R.; SATO, A.J.; BRENER, E.A.; JUBILEU; B.S.; SANTOS, E.S.; GENTA, W. Caracterização da fenologia e exigência térmica (graus-dias) para a uva 'Cabernet Sauvignon' em zona subtropical. Revista Brasileira de Fruticultura, v.27, p.183-187, 2005.

ROLIM, G.S.; SENTELHAS, P.C. Planilhas no ambiente Excel ${ }^{\mathrm{TM}}$ para os cálculos de balanços hídricos; normal, seqüencial, de cultura e de produtividade real e potencial. Revista Brasileira de Agrometeorologia, v.6, p.133-137, 1998.

RUSSO, G. Ripening process of two orange cultivars: Washington Navel and Navelina. Proceedings of the International Society of Citriculture, v.2, p.523-528, 1984.

SAS INSTITUTE INC. SAS/STAT user's guide. Version 8.2. Cary, 2001.

SOUZA, P.R. Alguns aspectos de influência do clima e temperatura sobre a cultura do arroz irrigado no sul do Brasil. Lavoura Arrozeira, v.43, p.9-11, 1990

THORNTHWAITE, C.W.; MATHER, J.R. The water balance. New Jersey: Laboratory of Climatology, 1955. 104p. (Publications in Climatology, 8).

VOLPE, C.A. Fenologia dos citros. In: SEMINÁRIO INTERNACIONAL DE CITROS, 2., Bebedouro, 1992. Anais. Campinas: Fundação Cargill, 1992. p.107-120.

VOLPE, C.A.; SCHÖFFEL, R.R., BARBOSA, J.C. Influência de algumas variáveis meteorológicas sobre a qualidade dos frutos das laranjeiras 'Valência' e 'Natal'. Revista Brasileira de Agrometeorologia, v.8, p.85-94, 2000.

VOLPE, C.A.; SCHÖFFEL, R.R.; BARBOSA, J.C. Influência da soma térmica e da chuva durante o desenvolvimento de laranjas- 'Valência' e 'Natal' na relação entre sólidos solúveis e acidez no índice tecnológico do suco. Revista Brasileira de Fruticultura, v.24, p.436-441, 2002.

WARRINGTON, I.J.; KANEMASU, E.T. Corn growth response to temperature and photoperiod. I. Seedling emergence, tassel initiation and anthesis. Agronomy Journal, v.75, p.749-754, 1983.

$\overline{\text { Received April 01 }}, 2005$

Accepted April 28, 2006 